\title{
EFFICIENCY OF INPATIENT LAYOUT IN PRIVATE HOSPITAL (Case Study: Bhakti Asih Hospital, Brebes Central Java)
}

\author{
Sri Hartuti Wahyuningrum ${ }^{1}$ ) Mustika K. Wardhani2*) \\ *) Corresponding author email : mk1698@fc.ritsumei.ac.jp \\ 1)Departemen Arsitektur, Fakultas Teknik, Universitas Diponegoro, Indonesia \\ 2) Research Organization of Open Inovation and Collaboration, Ritsumeikan University, Japan
}

\author{
Article info \\ MODUL vol 20 no 1, issues period 2020 \\ Doi $\quad: 10.14710 / \mathrm{mdl} .1 .1 .2020 .1-9$ \\ Received : 16 januari 2020 \\ Revised : 10 februari 2020 \\ Accepted : 29 maret 2020
}

\section{Abstract}

In the context of hospital building, inpatient care has large portion in comparasion of the other facility areas within hospitals related to efficiency, such as outpatient services, emergency room, diagnostic and especially inpatient function group services. Even though inpatient care group do not have specific requirements for detailed design and building equipment, it requires efficiency considerations related to correlation with room layout. It is expected that by considering the level of efficiency of service to patients, design can fulfill technical requirements of health and medical aspects. Regarding designs for district-level private hospitals, demand optimization of placement and layout of inpatient care became main topic in this research. This is related to the value of investment in building area development and types of services provided according to inpatient services class. The method used is comparative study of two (2) private hospital design to find the mind factors that most influence of optimization of inpatient layout. The results of study can be used as a guide in architectural design process for designing hospital buildings especially related to design efficiency of inpatient layout so that the building can function sustainability because of optimal service.

Keywords: Inpatient Care; Room Layout; Design Efficiency; Service Optimization

\section{Introduction}

In the law number 44 years 2009 regarding hospital article 10 paragraph (2) mention, hospital building as reffered to in paragraph (1) at least consists of room: b. Inpatient care. In the third part about Sri Hartuti Wahyuningrum, Mustika K. Wardhani buildings, Article 9 point (b) mention that technical requirements of hospital building, according to function, comfort \& ease to service delivery and protection and safety for all patient such as people with disabilities children, and elderly. Hospital layout and room built contributed to technical efficiency and work safety (Facility Guidelines Institute [FGI], 2010, in Zadeh et al, 2012).

..The size of the room is one variable that may be associated with the existing theoretical dimensions because it may signal the possibility of perceived control and the possibility of social support. In the literature, there is increasing emphasis on the concept of a rightsized room, one that meets needs for a patient-centered approach yet wastes no space. (http://www.healthcare designmagazine.Com/article/increasing-patientsatisfaction-decreasingpatient-room-sizebalances efficiency).

Safe and comfortable inpatient layout are main factors that can affect healing process for patients. Design of inpatient room with accommodating size is expected can be in accordance with requirements that support of healthy inpatient room, safe and comfortable for patients and also medical service units. With the different care class hierarchy, it becomes an opportunity to make efficiency, especially related to room size, layout configuration and supporting facilities related to inpatient care.

..Phychiatric facilities should enchance patients's dignity, self esteem and comfort as well as promoting autonomy and ensuring safety (Hoskins and Marshall, 2002).

..Confusing layouts can add to patients'anxiety (Landro, 2014) and uncertainty in patient flows challenges strategic decision making in health care (Blumenthal, 2009).. 
Appropriate design with an understanding of the facilities that should be available and area that fulfill requirements become dominant variable as basis for inpatient room lay out design in context of developing district-level private hospitals.

Constraints on land area limitations because both availability of site area and from investment context will cause need of efficiency in space area. In this condition, study of design efficiency of inpatient layout is needed which technically has relatively dominant portion of the overall hospital area.

This research can be reference for architects/professionals, stake holder (hospital owner) or institutions related to health services, especially in understanding the design concept of inpatient layout in hospital buildings that fulfill technical requirements and can accommodate service performance function.

\section{Methods of Research}

Method used in this research is descriptive analysis of main factor which has impact of optimization of two comparative design layout of inpatient room in private hospital. Whereas to find dominant factor that give an impact for optimization is to compare the design of existing room layouts by examining observational indicators one by one.

..Research on hospital rooms has focused on the impact of specific features of the physical environment (such as the view, Ulrich, 1984; or the occupancy/typology of the rooms, Shepley, Harris, \& White, 2008); or on the effect of overall improvements (e.g., Rice, Ingram, \& Mizan, 2008), most of them using correlational or quasi-experimental designs.

Observation variables used in identifying optimization of inpatient room design include: (X1) division of hierarchy class related to the number of bed in room; (X2) Total area of inpatient room related medical service activities (X3) type of medical services; (X4) and room facilities. Schematic of research flow can be seen in Figure 1:

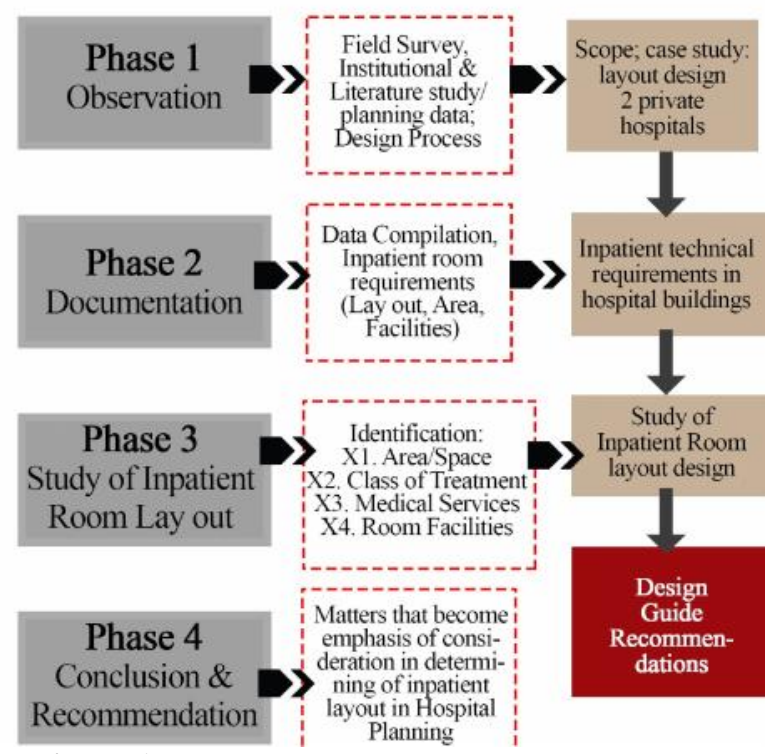

Figure 1. Flowchart of research stage (author, 2019)

Research phase consisted of observations, especially object of case study in this research is private hospital building ( 2 sample) followed by documentation, study of inpatient layout design according to latest literature and final stage leads to conclusion and recommendation compiled from results of analysis which form the basis of consideration used for inpatient room design .

\section{Study Literature}

1. Inpatient Room Design, Consists of (1) Nursing Unit which is service area for patients as hospital facilities, includes patient's bedroom, supporting room and staff room.

..Planning for efficient operation involving various plan types where patients were observed from the central nursing station (Kliment 2000)..

The location of nursing station should have proximity to inpatient room it serves, so the control of patients becomes more effective and efficient. So the function of control becomes main point for patients and nurses.

..A study of 6300 randomly selected nurses found that the highest risk of violence to staff was working in a nursing home/long-term care facility, followed by intensive care units, psychiatric units and emergency departments and that the risk of physical assault was highest when working with geriatric patients (Gerberich et al., 2004). 
Placement of inpatient care usually be one separate floor or being part of building wing in hospital area. Inpatient care can be one patient bed module or consist of several patient modules in one room depends on room class. Patient Module Requirements are understood as one health care unit for one or more patients served from one nurse station.

..The size of nursing units are determined according to how many patients can be cared by the certain number of personnel (Aydýn, 2004).

Inpatient care should be separate from other medical public services, while the nurse station located at the easy point for control over patient, with minimum ratio of 1 nurse station for maximum of 35 patient beds. The area of inpatient care should be able to suffice its breadth for service of nurses and patient movement. Supporting facilities such as toilets easily accessed from inpatient room.

2. Activity Flow in Inpatient Room, The flow of activities in Inpatient building are shown in Figure 2 below:

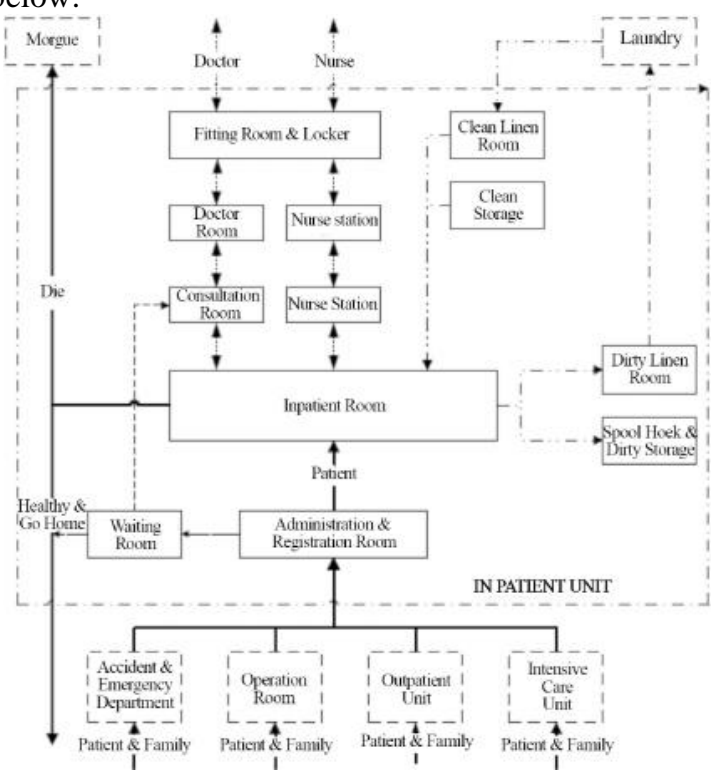

Figure 2. Re-draw Flowchart of Activities in Inpatient care (source: Directorate of Medical Support Services and Health Facilities, Indonesian Ministry of Health, 2012)

There are two activities in Inpatient room as follows below:

- $\quad$ Flow of Doctors, Nurses, and staff

(a) Preparation

(1) Doctor enters room to change clothes.
(2) Nurses, enter nurse's room to change clothes.

(3) Staff, enter the staff room to change clothes

(b) After completing jobs

(1) Doctor, nurse, staff go out through same way

- Patient flow

(a) Patients enters inpatient room

(1) Patient enters inpatient room from emergency room/central operation theatre (COT)/Outpatient treatment through admission

(2) Patients get medical record number

(3) handover \& orientation in nurse station

(4) patients change their clothes

(5) Patients further treated in inpatient room

(b) Patient leaves inpatient room

(1) Patient returns home after being healthy, or

(2) Dead patient will be deliver to mortuary

3. Technical Requirements for Inpatient Room in Hospital Buildings

(a) Location, inpatient buildings should be located in quiet location based on site analysis, safe and comfortable, but still has easy accessibility or proximity to supporting facilities. Inpatient building located far from landfill area, and away from engine/generator noise.

(b) Plan, (1) Room grouping is based on similar activity groups so each activity doesn't mix and not confusing building users; (2) Room placement, especially as a whole should be space to space connected with priority scale that should be close and related; (3) proximity access to each block/room should be easy reached; (4) moving speed is one of keys to successful design, so the unit block should be designed with the concept of linearly circulated/straight (lengthways); (5) the amount of room needs should be adjusted with the number of patients that will be accommodated; (6) morning sunlight as much as possible enter the room; (7) flow of staff and visitors are separated; (8) the amount of room and room capacity should be able to fulfill minimum requirements as shown in table 1 (see table 1 ): 
Table 1. Minimum space requirements in inpatient care (source: Directorate of Medical

Support Services and Health Facilities,

Indonesian Ministry of Health, 2012)

\begin{tabular}{clcc}
\hline $\begin{array}{c}\text { Nu } \\
\mathbf{m b} \\
\mathbf{e r}\end{array}$ & \multicolumn{1}{c}{ Room Name } & $\begin{array}{c}\text { Area } \\
(+)\end{array}$ & Unit \\
\hline 1 & Inpatient Room: & & \\
& VIP & 18 & $\mathrm{~m}^{2} / \mathrm{bed}$ \\
& Class I & 12 & $\mathrm{~m}^{2} / \mathrm{bed}$ \\
& Class II & 10 & $\mathrm{~m}^{2} / \mathrm{bed}$ \\
& Class III & 7.2 & $\mathrm{~m}^{2} / \mathrm{bed}$ \\
& Nurse station & 20 & $\mathrm{~m}^{2}$ \\
Consultation room & 12 & $\mathrm{~m}^{2}$ \\
& Operating room & 24 & $\mathrm{~m}^{2}$ \\
& Administration & 9 & $\mathrm{~m}^{2}$ \\
& room & & \\
Doctor Room & 20 & $\mathrm{~m}^{2}$ \\
Nurse Station & 20 & $\mathrm{~m}^{2}$ \\
Fitting Room/ & 9 & $\mathrm{~m}^{2}$ \\
Locker & & \\
Head of inpatient & 12 & $\mathrm{~m}^{2}$ \\
care room & & \\
Clean linen room & 18 & $\mathrm{~m}^{2}$ \\
Dirty linen room & 9 & $\mathrm{~m}^{2}$ \\
Spoelhoek & 9 & $\mathrm{~m}^{2}$ \\
toilet & 25 & $\mathrm{~m}^{2}$ \\
Pantry & 9 & $\mathrm{~m}^{2}$ \\
Janitor & 9 & $\mathrm{~m}^{2}$ \\
Room/Service & & \\
Clean Storage & 18 & $\mathrm{~m}^{2}$ \\
Dirty Storage & 18 & $\mathrm{~m}^{2}$ \\
\hline
\end{tabular}

(c) Inpatient room type, consist of (1) inpatient room 1 bed each room (VIP); inpatient room 2 bed each room (class 1); inpatient room 4 bed each room (class 2); inpatient room 6 bed or more each room (class 3 ).

(d) Specific patient requirements (isolation room), as: (1) patients suffering from infectious diseases; (2) Patients with treatment that causes stink (tumor disease, gangrene, diabetes); (3) Rowdy \& uneasy patient (issued noise in room).

\section{Rationale for Case Study Selection}

Case studies are determined based on consideration of private hospitals requires efficiency studies in relation to savings operational costs of health services, especially in inpatient care. As private hospital, Bhakti Asih Brebes hospital has been operating in Brebes city (1) and Bhakti Asih Jatibarang hospital is currently still doing construction (2).

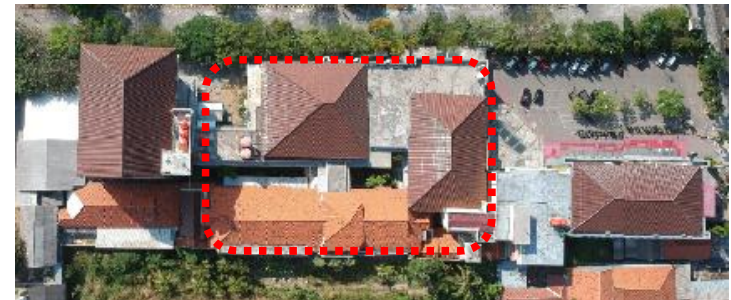

Figure 3. Inpatient building block Bhakti Asih Hospital Brebes

Inpatient care in Bhakti Asih Brebes Hospital as follows (see table 2):

Table 2. Layout plan comparasion of inpatient care $\left(2^{\text {nd }} \& 3^{\text {rd }}\right.$ floor) Bhakti Asih hospital Brebes (author, 2019)

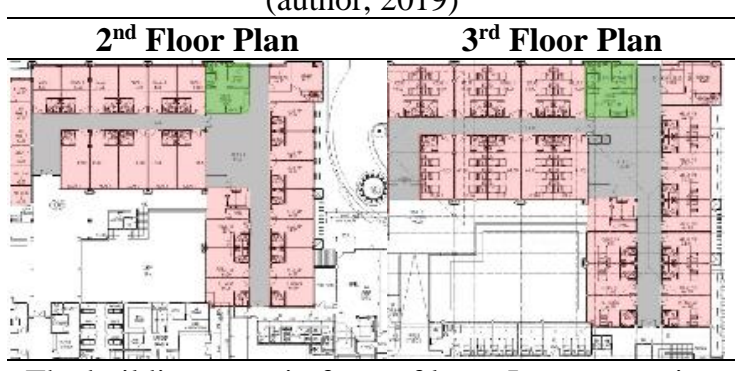

The building mass in form of letter L, nurse station position is in the middle (at a bend angle), modular trave room with variant of $3,5 \mathrm{~m} \& 4 \mathrm{~m}$, central corridor - corridor width $\mathbf{2 , 5} \mathrm{m}$ (double loaded), combination of room classes, vertical access by elevator.

While inpatient building at Bhakti Asih Jatibarang Hospital located in the back of building block, which is 3-storey building with inpatient area in $2^{\text {nd }} \& 3^{\text {rd }}$ floor connected to other service buildings on each floor.

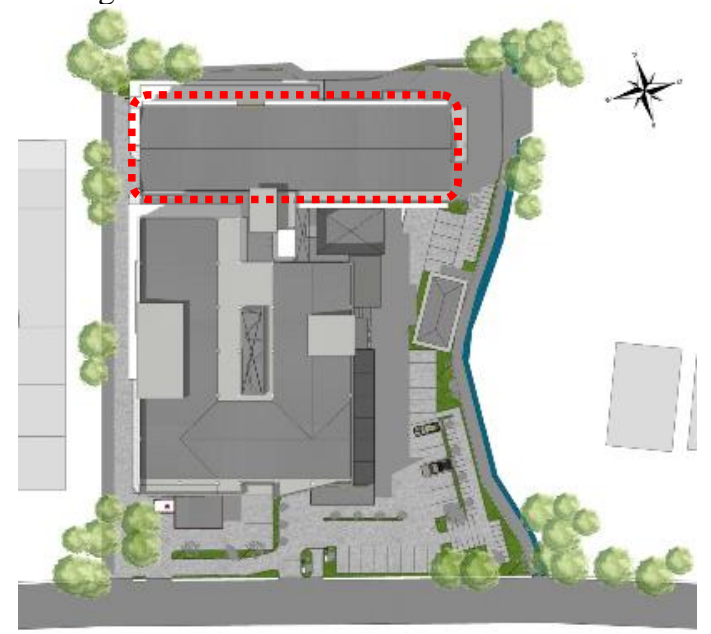

Figure 4. Inpatient Building Block, Bhakti Asih Hospital Jatibarang 
The inpatient lay out room as follows (see table 3 ):

Table 3. Comparasion of inpatient layout $2^{\text {nd }} \& 3^{\text {rd }}$ floor Bhakti Asih hospital Jatibarang (Author,

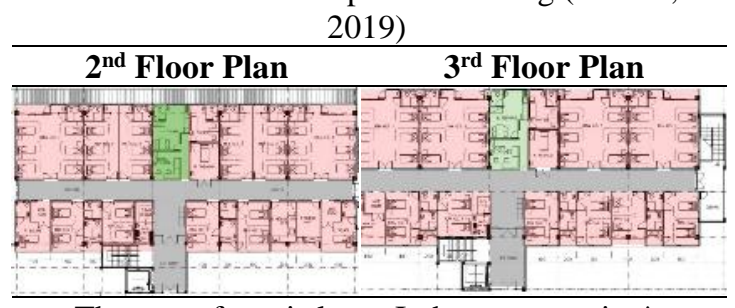

The mass form is letter I, the nurse station's position in the middle (near arrival area), modular space trave $4 \mathrm{~m}$, central corridor - corridor width $\mathbf{2 , 8} \mathrm{m}$ (double loaded), combination of classes, vertical access with elevators.

\section{Analysis}

The analysis in this research using a scientific method which is considered as a set of methods to prove or disprove one or more hypothesis. Hypothesis is an explanation proposed to see the phenomenon that occurs. This phenomenon is generally collected through observation of two observed objects or experiment which in this research is layout design. This was explained according to (Castillo, 2013):

.. The scientific method is better thought of as a set of "methods" or different techniques used to prove or disprove 1 or more hypotheses.

A hypothesis is a proposed explanation for observed phenomena. These phenomena are, in general, empirical-that is, they are gathered by observation and/or experimentation..

Concerned with spatial configuration and technical requirements in supporting special medical services especially regarding procedures for patient services related to lay out and inpatient care services. Inpatient layout indicator will determine efficiency of its services related to:

(1) Shape and size of building mass of inpatient care

(2) Placement of nurse station as service area to patients in inpatient care (ease of service access, controlling and service proximity).

(3) Bed layout in each inpatient room.

\section{Analysis of Mass Shape in Inpatient Building}

Building mass shape analysis of inpatient care will be explained in Table 4 below:
Table 4. Analysis of Inpatient Layout in Building Mass From (Author, 2019)

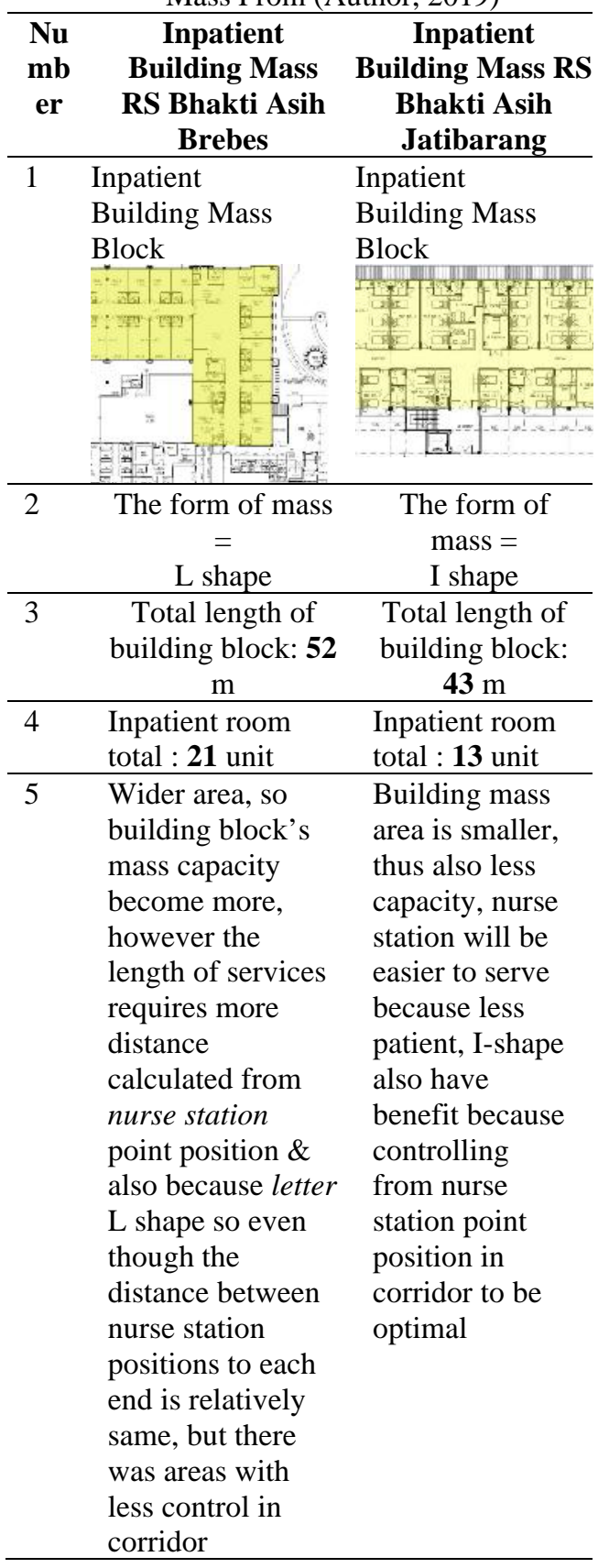

2. Placement of Nurse Station in Inpatient Block

The nurse station point in reaching patients is the main internal circulation in inpatient corridor so the traffic intensity is included in high criteria. According to (Bailey, 1956):

..Internal traffic means the movement of human beings and different materials in hospital. In general, spaces with high traffic in intensity should 
be close to each other while ones with low traffic can be far away; however, such factors as urgency, destination convenience may change configurations..

Proximity should be close to one another. The urgency and comfort factor can change layout configuration, as long as it remains in the realm of intense patient quality control. The placement of Nurse Station can be seen in Table 5 below:

Table 5. Nurse station placement in inpatient care RS Bhakti Asih Jatibarang (author, 2019)

\begin{tabular}{|c|c|c|}
\hline $\begin{array}{l}\mathrm{Nu} \\
\mathrm{mb} \\
\mathrm{er}\end{array}$ & $\begin{array}{l}\text { Nurse Station in } \\
\text { Inpatient Care } \\
\text { Bhakti Asih } \\
\text { Hospital Brebes }\end{array}$ & $\begin{array}{c}\text { Nurse Station in } \\
\text { Inpatient Care } \\
\text { Bhakti Asih } \\
\text { Jatibarang } \\
\end{array}$ \\
\hline 1 & 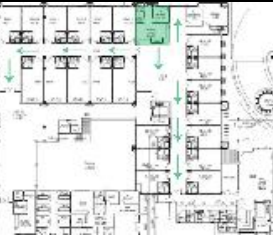 & 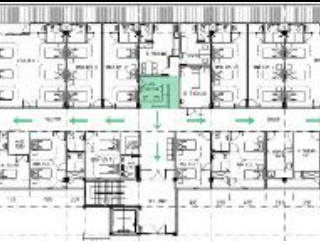 \\
\hline 2 & $\begin{array}{c}\text { Position at the } \\
\text { angle of building } \\
\text { mass }\end{array}$ & $\begin{array}{l}\text { Position in the middle } \\
\text { of building's length }\end{array}$ \\
\hline 3 & $\begin{array}{l}\text { Controlling over } \\
\text { longer corridors, } \\
\text { and one side is not } \\
\text { well monitored }\end{array}$ & $\begin{array}{l}\text { Controlling over } \\
\text { shorter corridors, same } \\
\text { length \& well } \\
\text { monitored }\end{array}$ \\
\hline 4 & $\begin{array}{l}\text { More service, } \\
\text { number of beds= } \\
\text { (37 bed unit) }\end{array}$ & $\begin{array}{l}\text { Less service, number } \\
\text { of beds }=(\mathbf{3 4} \text { bed unit })\end{array}$ \\
\hline 5 & $\begin{array}{l}\text { Entrance area, one } \\
\text { is not monitored } \\
\text { (there was } 2 \\
\text { entrance), lift area } \\
\text { is easily } \\
\text { accessible and } \\
\text { monitored }\end{array}$ & $\begin{array}{l}\text { Entrance area easily } \\
\text { monitored ( } 1 \\
\text { entrance), lift area is } \\
\text { easily monitored } \\
\text { because it become one } \\
\text { with entrance area }\end{array}$ \\
\hline
\end{tabular}

\section{Bed Lay Out In Inpatient Room}

Lay out bed in each inpatient room for same class, which in this case selected for class I with capacity of 2 beds each for class I. For class II Bhakti Asih Jatibarang hospital is not in same block and for class III with 6 beds in Bhakti Asih Brebes hospital placed in different mass blocks and for VIP class ( 1 beds) in principle almost same. The analysis of bed layout can be seen in Table 6 below:
Table 6. Bed layout analysis in Inpatient care (Author, 2019)

\begin{tabular}{|c|c|c|}
\hline $\begin{array}{l}\mathrm{Nu} \\
\mathrm{mb} \\
\mathrm{er}\end{array}$ & $\begin{array}{c}\text { Bed layout analysis in } \\
\text { inpatient room } \\
\text { (Bhakti Asih Brebes } \\
\text { Hospital) }\end{array}$ & $\begin{array}{c}\text { Bed layout analysis } \\
\text { in inpatient room } \\
\text { (Bhakti Asih } \\
\text { Jatibarang Hospital) }\end{array}$ \\
\hline 1 & Fin & E \\
\hline 2 & $\begin{array}{l}\text { Inpatient room class I: } \\
\text { capacity of each room = } \\
\mathbf{2} \text { beds }\end{array}$ & $\begin{array}{l}\text { Inpatient room class I: } \\
\text { capacity of each room } \\
=\mathbf{2} \text { beds }\end{array}$ \\
\hline 3 & $\begin{array}{l}\text { Room size : } \mathbf{4 \times 6} \mathrm{m}^{2} \\
\text { toilet include }\left(\mathbf{2} \times \mathbf{2} \mathrm{m}^{2}\right)\end{array}$ & $\begin{array}{l}\text { Room size : } 4 \times 6,2 \mathrm{~m}^{2} \\
\text { toilet include }\left(\mathbf{2 \times 2} \mathrm{m}^{2}\right)\end{array}$ \\
\hline 4 & $\begin{array}{l}\text { Toilet zone near coridor } \\
\text { (ease of maintenance } \\
\text { that does not disturb } \\
\text { patient rooms) }\end{array}$ & $\begin{array}{l}\text { Varian toilet zone: }(1) \\
\text { near coridor (ease of } \\
\text { maintenance that does } \\
\text { not disturb patient } \\
\text { rooms); (2) near, out } \\
\text { of building (less } \\
\text { maintenance access } \\
\text { and there was } \\
\text { interfence to patient's } \\
\text { room) }\end{array}$ \\
\hline 5 & $\begin{array}{l}\text { Bed configuration: in } \\
\text { line (standard) and } \\
\text { fulfill criteria for ease } \\
\text { of access, including } \\
\text { proximity to main } \\
\text { entrance. }\end{array}$ & $\begin{array}{l}\text { Bed configuration: in } \\
\text { line (standard) \& } \\
\text { fulfill criteria of ease } \\
\text { access, including } \\
\text { proximity to main } \\
\text { entrance. }\end{array}$ \\
\hline & $\begin{array}{l}\text { Smaller inpatient room } \\
\text { (less comfort and } \\
\text { privacy), including } \\
\text { adequate view out \& not } \\
\text { blocked by toilet area }\end{array}$ & $\begin{array}{l}\text { Wider patient room } \\
\text { (more patient comfort } \\
\text { and privacy), } \\
\text { including adequate } \\
\text { view out \& not } \\
\text { blocked by toilet area }\end{array}$ \\
\hline
\end{tabular}

\section{Conclusion}

Conclusions conducted after the results of analysis in the form of understanding and study which significant with inpatient room. Indicators of room optimization consist of: building mass shape, nurse station placement and inpatient room lay out are each reviewed in terms of discussion context. Conclusions of study can be explained into results (see Table 7) as follows : 
Table 7. Conclusions and results of research (author, 2019)

\begin{tabular}{|c|c|c|c|}
\hline $\begin{array}{c}\mathrm{Nu} \\
\mathrm{mb} \\
\mathrm{er}\end{array}$ & $\begin{array}{c}\text { Bhakti Asih } \\
\text { Hospital } \\
\text { Brebes }\end{array}$ & $\begin{array}{c}\text { Bhakti Asih } \\
\text { Hospital } \\
\text { Jatibarang }\end{array}$ & Conclusion \\
\hline 1 & \multicolumn{3}{|c|}{$\begin{array}{c}\text { Study of Mass Forms in Inpatient Room } \\
\text { Buildings }\end{array}$} \\
\hline & $\begin{array}{c}\text { Building } \\
\text { mass= Letter } \\
\text { L }\end{array}$ & $\begin{array}{c}\text { Building } \\
\text { mass= Letter I }\end{array}$ & \multirow{4}{*}{$\begin{array}{l}\text { Building mass } \\
\text { with letter I is } \\
\text { more efficient } \\
\text { Because it's } \\
\text { easier to reach } \\
\text { from nurse } \\
\text { stationnya } \\
\text { placement } \\
\text { point \& easy } \\
\text { for monitoring } \\
\text { because of } \\
\text { simplicity } \\
\text { shape, the } \\
\text { number of } \\
\text { service units } \\
\text { can also be } \\
\text { optimized } \\
\text { (related to } \\
\text { number of } \\
\text { beds per } \\
\text { service floor) }\end{array}$} \\
\hline & $\begin{array}{c}\text { Total length } \\
\text { of building } \\
\text { block mass: } \\
\mathbf{5 2 m}\end{array}$ & $\begin{array}{l}\text { Total length of } \\
\text { building block } \\
\text { mass: } 43 \mathrm{~m}\end{array}$ & \\
\hline & $\begin{array}{l}\text { Amount of } \\
\text { inpatient } \\
\text { room: } \\
\mathbf{2 1} \text { unit }\end{array}$ & $\begin{array}{l}\text { Amount of } \\
\text { inpatient } \\
\text { room: } \\
\mathbf{1 3} \text { unit }\end{array}$ & \\
\hline & $\begin{array}{l}\text { Wider area, } \\
\text { so building } \\
\text { block's mass } \\
\text { capacity } \\
\text { become more, } \\
\text { however the } \\
\text { length of } \\
\text { services } \\
\text { requires more } \\
\text { distance } \\
\text { calculated } \\
\text { from nurse } \\
\text { station point } \\
\text { position \& } \\
\text { also because } \\
\text { letter L shape } \\
\text { so even } \\
\text { though the } \\
\text { distance } \\
\text { between } \\
\text { nurse station } \\
\text { positions to } \\
\text { each end is } \\
\text { relatively } \\
\text { same, but } \\
\text { there was } \\
\text { areas with } \\
\text { less control in } \\
\text { corridor }\end{array}$ & $\begin{array}{l}\text { Building mass } \\
\text { area is smaller, } \\
\text { thus also less } \\
\text { capacity, nurse } \\
\text { station will be } \\
\text { easier to serve } \\
\text { because less } \\
\text { patient, letter I } \\
\text { shape also } \\
\text { have benefit } \\
\text { because } \\
\text { controlling } \\
\text { from nurse } \\
\text { station point } \\
\text { position in } \\
\text { corridor to be } \\
\text { optimal }\end{array}$ & \\
\hline
\end{tabular}

2. Nurse Station Placement Study in Inpatient Room

\begin{tabular}{|c|c|c|}
\hline $\begin{array}{l}\text { Position: } \\
\text { angle of } \\
\text { uilding mass }\end{array}$ & $\begin{array}{l}\text { Position: in } \\
\text { middle of } \\
\text { building mass }\end{array}$ & $\begin{array}{c}\text { with } I \text {-shape, } \\
\text { nurse station's } \\
\text { placement }\end{array}$ \\
\hline $\begin{array}{l}\text { Controlling } \\
\text { ver longer } \\
\text { rridors, and }\end{array}$ & $\begin{array}{l}\text { Controlling } \\
\text { over shorter } \\
\text { corridors, }\end{array}$ & $\begin{array}{l}\text { be controlled } \\
\text { for farthest } \\
\text { service }\end{array}$ \\
\hline
\end{tabular}

\author{
one side is \\ not well \\ monitored \\ More service, \\ number of \\ beds $=$ \\ (37 bed unit) \\ Entrance \\ area, one is \\ not monitored \\ (there was 2 \\ entrance), lift \\ area is easily \\ accessible \\ and \\ monitored
}

same length \& well monitored

Less service, number of

beds $=(\mathbf{3 4}$ bed unit)

Entrance area easily

monitored (1

entrance), lift

area is easily monitored

because it

become one

with entrance distance and controlling to all corridors become easier. Thus, service to patients more efficient (effective amount of beds, distance to patient's room is closer so it's more efficient)

\begin{tabular}{|c|c|c|c|}
\hline 3. & \multicolumn{3}{|c|}{ Study of Bed Lay Out in Inpatient Room } \\
\hline & $\begin{array}{c}\text { Inpatient } \\
\text { room class I: } \\
\text { capacity of } \\
\text { each room = } \\
2 \text { beds }\end{array}$ & $\begin{array}{l}\text { Inpatient room } \\
\text { class I: } \\
\text { capacity of } \\
\text { each room }=2 \\
\text { beds }\end{array}$ & $\begin{array}{c}\text { For lay out } \\
\text { study in } \\
\text { Inpatient room } \\
\text { class I } \\
\text { (capacity of } 2 \\
\text { patient } \\
\text { beds/room), } \\
\text { Bhakti Asih } \\
\text { Jatibarang } \\
\text { hospital's } \\
\text { patients get a } \\
\text { larger room } \\
\text { area so better } \\
\text { for patient's } \\
\text { comfort and } \\
\text { privacy, for } \\
\text { layout in } \\
\text { principle there } \\
\text { are no } \\
\text { significant } \\
\text { differences so } \\
\text { the service is } \\
\text { quite efficient } \\
\text { (patient's bed } \\
\text { position are } \\
\text { fulfil } \\
\text { requirement) }\end{array}$ \\
\hline
\end{tabular}

\begin{tabular}{cc|}
\hline 3. & Study of Bed Lay Out in Inpatient Room \\
\hline Room size: & Room size: \\
$4 \times 6 \mathrm{~m}^{2}+$ & $4 \times 6,2 \mathrm{~m}^{2}+$
\end{tabular}




\begin{tabular}{|c|c|}
\hline $\begin{array}{l}\text { toilet include } \\
\left(2 \times 2 \mathrm{~m}^{2}\right) \\
\text { Toilet zone } \\
\text { near corridor } \\
\text { (ease of } \\
\text { maintenance } \\
\text { \& does not } \\
\text { disturb } \\
\text { patient } \\
\text { rooms) }\end{array}$ & $\begin{array}{l}\text { toilet include } \\
\left(2 \times 2 \mathrm{~m}^{2}\right) \\
\text { Toilet zone } \\
\text { near corridor } \\
\text { (ease of } \\
\text { maintenance \& } \\
\text { does not } \\
\text { disturb patient } \\
\text { rooms) come } \\
\text { are near } \\
\text { outside edge of } \\
\text { building (less } \\
\text { maintenance } \\
\text { access \& } \\
\text { disturb patient } \\
\text { room) }\end{array}$ \\
\hline $\begin{array}{c}\text { Bed } \\
\text { configuration: } \\
\text { in line } \\
\text { (standard) } \\
\text { and fulfill } \\
\text { criteria for } \\
\text { ease of } \\
\text { access, } \\
\text { including } \\
\text { proximity to } \\
\text { main } \\
\text { entrance. }\end{array}$ & $\begin{array}{c}\text { Bed } \\
\text { configuration: } \\
\text { in line } \\
\text { (standard) \& } \\
\text { fulfill criteria } \\
\text { of ease access, } \\
\text { including } \\
\text { proximity to } \\
\text { main entrance. }\end{array}$ \\
\hline $\begin{array}{c}\text { Smaller } \\
\text { inpatient } \\
\text { room (less } \\
\text { comfort and } \\
\text { privacy), } \\
\text { including } \\
\text { adequate view } \\
\text { out \& not } \\
\text { blocked by } \\
\text { toilet area }\end{array}$ & $\begin{array}{l}\text { Wider patient } \\
\text { room (more } \\
\text { patient } \\
\text { comfort and } \\
\text { privacy), } \\
\text { including } \\
\text { adequate view } \\
\text { out \& not } \\
\text { blocked by } \\
\text { toilet area }\end{array}$ \\
\hline
\end{tabular}

Based on analysis of all variables used and analysis, significant influential factor in inpatient layout efficiency is inpatient Room Facility (X4) which consists of the building mass shape and service proximity to nurse station, (room where the nurses standby) in context of large porsion in service to patients, as follow:

1. Easy access to services to each patient's room

2. Effective proximity from nurse station to each patient room

3. Ease for monitoring to the corridor, so patient feels safe and comfortable

4. For inpatient layout with same area and number of patient beds, even though have different configurations, it's not provide significant contribution to aspect of service efficiency, but more specific to context of comfort and privacy of patient room.

\section{Recommendation}

Research result can be recommended as design guide for lay out of inpatient room. Especially in variable $=(\mathrm{X} 4)$ Inpatient Room Facilities to obtain optimal layout results in terms of service to patients, hospital layout designs especially layout in inpatient room should be :

1. Considering the character of building mass \& form (simpler shape of building mass is more optimal for room layout configuration).

2. Considering the placement of nurse station in building mass related to proximity of services, easy access \& monitoring.

3. Considering area and layout of inpatient rooms according to hospital design technical requirement especially in private hospital.

\section{Acknowledgement}

Author would like to thank The Faculty of Engineering, Diponegoro University for funding the strategic research proposed in fiscal year 2019.

\section{References}

Aydin, D. (2004) 'Hastane Binalarýnýn Mekansal Kurgusu Üzerine, Hastane-Hospital News.'

Bailey, N.T.J. (1956) 'Statistics in Hospital Planning and Design, Applied Statistics', (vol. 5, no. 3) pp.146-157

Blumenthal, D. (2009). 'Stimulating the adoption of health information technology', New England Journal of Medicine, 360(15), 1477-1479.

Castillo, M. (2013) 'The Scientific Method: A Need for Something Better?', AJNR Am J Neuroradiol 34:1669-73 www.ajnr.o http://dx.doi.org/10.3174/ajnr.A3654

Gerberich, S. G. et al. (2004) An epidemiological study of the magnitude and consequences of work related violence: the Minnesota Nurses' Study, Occupational Environmental Medicine, 61, 495503

Hoskins, G. and Marshall, M. (2002). 'Expect more: making a place for people with dementia'. In Jacoby, R. and Oppenheimer, C. (eds.), Psychiatry in the Elderly, 3rd edn (pp. 460-483). Oxford: Oxford University Press.

Kliment, S. (2000) Building Type Basics for Healthcare Facilities, John Wiley \& Sons, Canada'

Landro, L. (2014) 'A Cure for hospital designstrategies to keep patients and their visitors from getting lost.' The Wall Street Journal

Zadeh, Rana Sagha et al,. (2012). 'Rethinking Efficieny in Acurate Care Nursing Units: 
Analyzing Nursing Units Layouts for Improved Spatial Flow'. Health Environments Research \& Design Journal. 6(1)39. http://dx.doi.ORG/10.1108/02656711011035129.

----, (2002) New Zealand Ministry of Health. Criteria for the design and refurbishment of psychiatric acute and intensive care facilities: a statement from the Ministry of Health. Available at: http://www.moh.govt.nz/moh.nsf/7004be0c19a98f 8a4c25692e007bf833

----, (2002) Healthcare Facilities Statistical annual. Research Planning and Coordination Council, Republic of Turkey Ministry of Health. Ankara. (accessed: January 31st, 2004). Available: http://www.saglik.gov.tr

----, (2002) Undang-undang Republik Indonesia Nomor 28 Tahun 2002 tentang Bangunan Gedung

----, (2006) Peraturan Menteri Pekerjaan Umum Nomor 29/PRT/M/2006 Tanggal 1 Desember 2006 tentang Pedoman Persyaratan Teknis Bangunan Gedung

----, (2012) Pedoman Teknis Bangunan Rumah Sakit Ruang rawat inap, Direktorat Bina Pelayanan penunjang Medik dan Sarana Kesehatan Direktorat Bina Upaya Kesehatan Kementerian Kesehatan RI

(http://www.healthcaredesignmagazine.Com/article/inc reasing-patient-satisfaction-decreasingpatientroom-sizebalances efficiency). 